\title{
Acute Gastric Dilatation in Cats: A Case Series
}

\author{
By W.P. Bredal ${ }^{1}$, A.V. Eggertsdóttir ${ }^{1}$ and $\emptyset$. Austefjord ${ }^{2}$
}

Department of Small Anımal Clinıcal Sciences, Norwegıan College of Veterınary Medıcıne, Oslo, and Nøtterøy Small Anımal Clınıc, Nøtterøy, Norway.

\begin{abstract}
Bredal, W.P., A.V. Eggertsdóttir and $\varnothing$. Austefjord: Acute gastric dilatation in cats: A case series. Acta vet. scand. 1996, 37, 445-452. - Acute gastric dilatation (AGD) is a well-known, acute, life-threatening disease in dogs but its felıne counterpart is much less known. This paper provides descriptions of 2 cases of AGD in cats that the authors have seen. Including these a total of 10 cases of feline AGD have been reported. No breed or sex predilection was found among the cases Age distribution ranged from 11 weeks to 13 years. All 10 cats with AGD had enlarged abdomens on presentation. In 3 of the cases this was the only presentıng sign and all 3 were simple, uncomplicated gastric dilatations, that were easily corrected by gastric decompression. Four of the 10 cats with AGD had dyspnea in addition to enlarged abdomens and only one of these cats survived, suggesting that this combination of clinical signs might indicate a guarded prognosis. Five out of the 10 cats with AGD had gastric torsion, 2 of these with concomittant diaphragmatic hernia. Four of the 5 cats with gastric torsion survived after appropriate surgery. Diaphragmatic hernia was a concurrent condition in 3 cats with signs of AGD.

A mortality of $30 \%$ was observed in cats with AGD. Treatment was successful in 7 out of 10 cases and consisted of shock therapy combined with gastric decompression or surgery. Prognosis seems favorable once the initial acute stage has been overcome. Recurrence has only been recorded in one cat

Conclusions drawn from the available material are. 1) clinical signs and therapeutical management of AGD are similar in cats and dogs, 2) the age of the patients seem to differ between feline and canine AGD, 3) more information is needed to fully assess the prognosis and recurrence rate of feline AGD.
\end{abstract}

torsion; clinic.

\section{Introduction}

Acute gastric dilatation (AGD) is a well-known disease in dogs. However, it occurs in many species including man, monkeys, horses, ruminants, pigs, foxes, mink, captive wild carnivores, rabbits, nutria, guinea pigs, rats, mice and cats (Van Kruiningen et al. 1974). AGD is a life-threatening disease in which the stomach dilates and causes abdominal pain, hypovolemic shock due to impaired venous return to the heart, and acid-base and electrolyte disorders (Wingfield et al. 1976). The tympanic stomach may remain in position, or it may twist on its longitudinal axis producing gastric torsion. Untreated the condition leads to a rapid death.

To an experienced clinician there is usually little problem in diagnosing AGD, regardless of species, as the clinical signs of the disease at presentation are pathognomonic. The clinical signs are usually acute on-setting abdominal distension and pain, nonproductive retching, nausea and depression. If there is any doubt about the clinical diagnosis, stomach tube pas- 
sage, gastrocentesis or prompt abdominal radiography may provide the necessary information (Lippencott \& Schulman 1989).

This paper provides details of 2 feline cases of AGD seen by the authors, and 8 other cases that have been reported (Austefjord \& Bredal 1994, de Gresti \& Leonardi 1968, Herr et al. 1973, Key 1977, Kieval \& Dykes 1977, Nathans 1984, Scholl 1979, Turner 1968). The compiled findings of AGD in cats are reviewed and compared to AGD in dogs.

\section{Case 1}

On 27 August 1993, a four-year-old, castrated male domestic shorthaired cat was brought to Nøtterøy Small Animal Clinic with a $30 \mathrm{~min}$ history of acute pain and distress. The cat had suddenly without apparent reason started howling and groaning. It avoided the owner and fled into a nearby shrubbery where it was eventually caught.

\section{Clinical and radiographic findings}

When presented at the clinic the cat seemed to be in considerable discomfort. It was restless and moaned continuously. The physical examination revealed painful abdominal distension, marked dyspnea and mild dehydration. Rectal temperature, pulse and peripheral lymph nodes were normal, but the mucous membranes were pale.

In an attempt to relieve the abdominal distension, a stomach tube was passed. Sedation was not required and immediate relief was obtained as gas escaped through the tube. A visible reduction of the abdominal distension was observed. Right lateral and ventrodorsal radiographs were taken (Fig. 1a and 1b). Despite the observed and palpated reduction in distension, the radiographs showed large amounts of gas in the stomach, which was displaced towards the left side of the abdomen. Within minutes of having developed the radiographs, acute abdominal distension was again observed. Before further treatment was possible the cat died. Resuscitation was unsuccessful.

\section{Autopsy}

After obtaining the owners consent, a field autopsy was performed immediately. Apart from severe abdominal distension caused by an extremely dilated stomach, the only other significant finding was 7 milliliters of serous transudate in the pericardium. The spleen was normal. The diaphragm was intact, and no signs of gastric torsion were found.

\section{Case 2}

On 2 December 1980 an 18-month-old, intact male domestic shorthaired cat was brought to the Emergency Clinic of the Norwegian College of Veterinary Medicine with acute abdominal distension. The cat had been hit by a car 3 weeks earlier. According to the owner, the cat had only eaten small amounts of food since the accident. However, on the day when it was presented at the clinic it had eaten more than usual. Shortly after feeding, the owner noticed that the cat was in respiratory distress, foaming at the mouth, and had a distended abdomen.

\section{Clinical findings and treatment}

When presented at the clinic the cat was in severe respiratory distress. The abdomen was distended and tympanic. The mucous membranes were very pale. Because the cat was in respiratory distress, no attempt to pass a stomach tube was made. Instead, gastrostomy was performed under local anaesthesia in the right flank, and the stomach was flushed with water. Visible relief was obtained, and fluid and antibiotic therapy was initiated. The gastrostomy site was closed the following day and fluid and antibiotic therapy was continued. However, the cat 
died suddenly prior to a scheduled radiographic examination.

\section{Autopsy}

Autopsy revealed an acute, diffuse peritonitis and pleuritis. The diaphragm was ruptured ventrally, and most of the spleen, omentum and a part of the liver were found in the thoracic cavity. The stomach was dilated with patches of necrosis. There were atelectasis of the lungs on the left side. Histopathological examination of routinely stained tissue revealed a chronic interstitial pneumonia.

\section{Literature review}

A literature study was made by computerized search of the veterinary journals covered by the Commonwealth Agricultural Bureau index from 1972 to 1996. A supplementary manual search for cases prior to 1972 was conducted by searching the indices of major veterinary journals and of the reference lists provided in relevant papers.

Eight cases of AGD in cats had previously been described (de Gresti \& Leonardi 1968, Herr et al. 1973, Key 1977, Kieval \& Dykes 1977, Nathans 1984, Scholl 1979, Turner 1968). Adding our 2 cases makes a total of 10 reports of AGD in cats (Table 1). No breed predilection was found, however, the breed was not reported in 4 cases (case nos. 4, 7, 8, and 9). Sex distribution of the reported cases showed 5 male and 4 female cats. In one case sex was not reported (case no. 7). Age distribution ranged from 11 weeks to 13 years, with 5 cats above (cases nos. $1,3,4,7$, and 8 ), and 5 cats below 2 years of age (cases nos. 2, 5, 6, 9, and 10). In addition to these findings, treatment, outcome and recurrence are summarized in Table 1. A mortality of $30 \%$ was observed.

All 10 cats with AGD had enlarged abdomens on presentation. Four of the cases were pre-
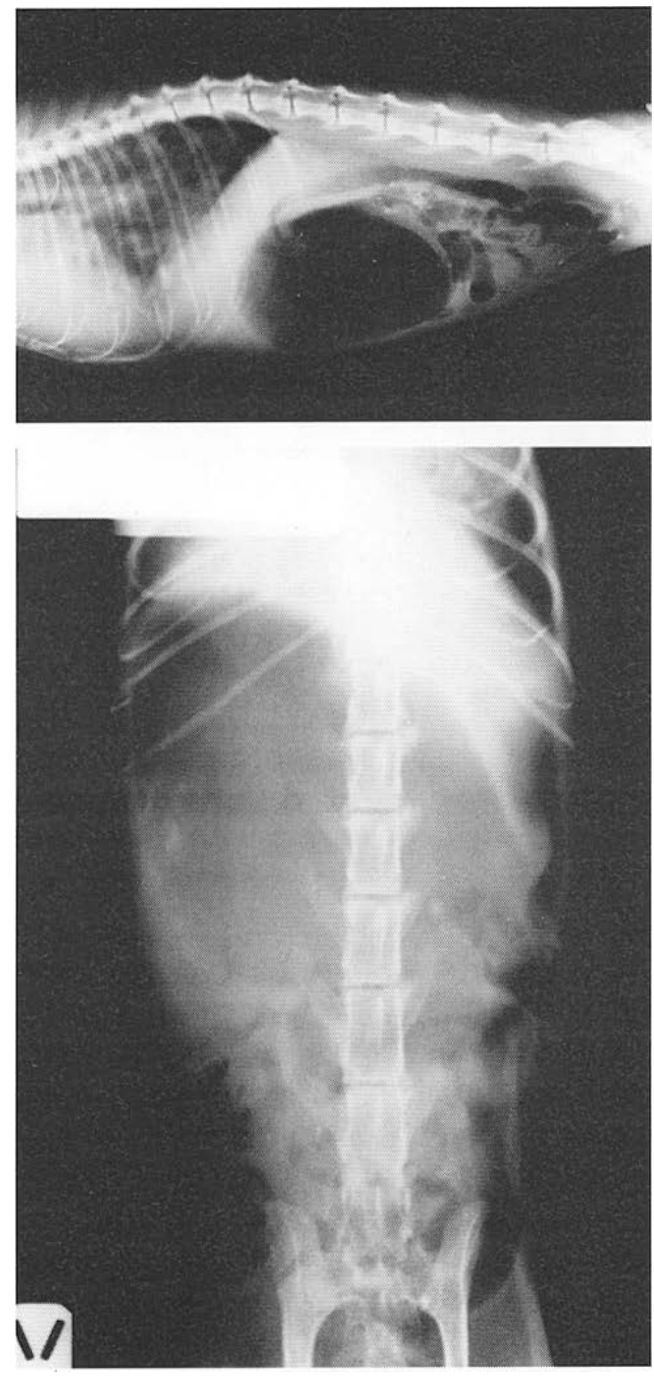

F1gure 1. Right lateral (a) and ventrodorsal (b) radiographs taken immediately following gastric intubation of Case 1. Notice that in spite of grossly visible and palpable relief gained by intubation, large amounts of gas remain confined in the stomach.

sented without signs of shock (cases nos. 4, 7 , 8, and 9), and 3 of these (cases nos. 7, 8, and 9) were easily corrected by gastric decompression. Four of the 10 cats with AGD had dyspnea in 


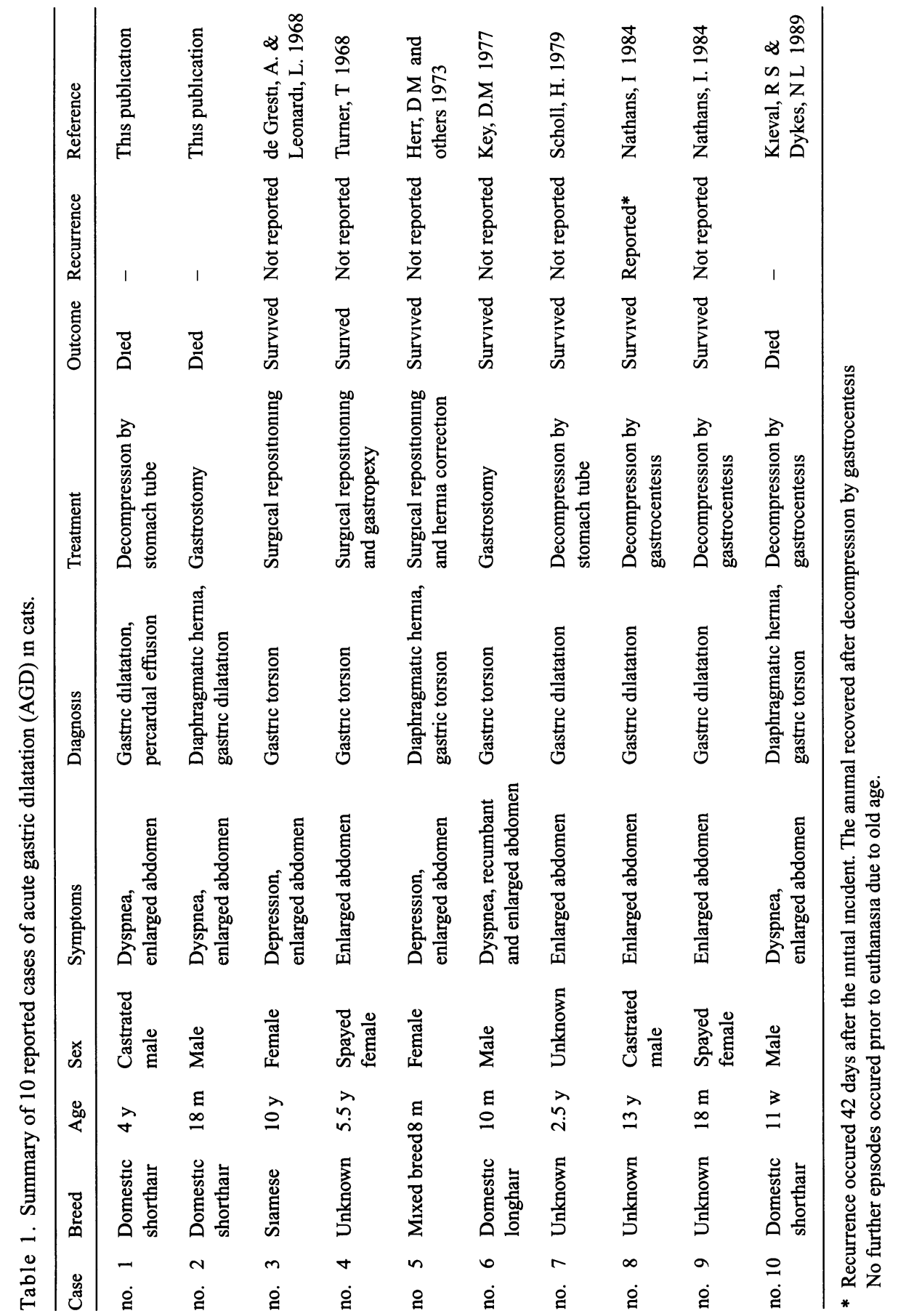


addition to enlarged abdomens (cases nos. 1, 2, 6 , and 10). Only one of these cats survived (case no. 6), suggesting that this combination of clinical signs might indicate a guarded prognosis. One of the 4 had gastric torsion (the survivor), one had diaphragmatic hernia (case no. 2), one had concomittant gastric torsion and diaphragmatic hernia (case no. 10), and the last cat had pericardial effusion at autopsy (case no. 1). Five out of the 10 cats with AGD had gastric torsion (cases nos. 3, 4, 5, 6, and 10), 2 of these with concomittant diaphragmatic hernia (cases nos. 5, and 10). Four of the 5 cats with gastric torsion survived after appropriate surgery (cases nos. 3, 4, 5, and 6), including one of the cats with both torsion and hernia. The final cat with gastric torsion succumbed prior to reaching the operating theatre (case no. 10).

\section{Discussion}

AGD in cats is a rare condition, seldom and only briefly referred to in textbooks on small animal medicine and surgery. However, the presenting clinical signs are easily recognized, probably due to familiarity with AGD in dogs. Therefore the diagnosis posed little problem to the practitioners involved in the 10 feline cases reported to date.

The treatment of canine AGD consists of 4 basic steps: 1) treating hypovolemic shock, 2) gastric decompression by orogastric intubation, gastrocentesis or gastrostomy, 3) surgical repositioning and fixation of the stomach (gastropexy) is necessary, and 4) postoperative supportive treatment, including fluid therapy, antibiotics, protection against reperfusion injury, and monitoring for development of cardiac arrhythmias (Lippencott \& Schulman 1989, Todoroff 1992, Eggertsdóttir 1995). Since corresponding standardized and generally accepted treatment procedures for AGD in cats are nonexistent, treatment has varied (Ta- ble 1). Treatment has therefore been based on alleviating the severity of the presenting clinical signs and on the practitioners experience.

Results in Table 1 indicate that gastric decompression by stomach tube or percutaneous gastrocentesis was adequate treatment for gastric dilation in cats. Gastric torsion, however, requires surgical treatment. Since 3 cats with gastric torsion had accompanying diaphragmatic hernia, surgery is not only necessary to reposition and secure the stomach, but also to correct any accompanying traumatic abdominal lesions.

Fifty-seven \% of dogs with AGD are between 4 and 9 years old (Todoroff 1992). Overall the affected cats are younger than affected dogs. Five out of 10 were less than 2 years old, and only 2 cats were older than 5.5 years. The 3 cats with diaphragmatic hernia were all young cats $(\leq 18$ months) and 2 of them were intact males. Younger animals are more accident prone, especially intact male cats.

AGD is most common in deep-chested dogs of large and giant breeds, although a few cases have been reported in small breeds (Turner 1964, Betts et al. 1974). Some of the more commonly recognized predisposing factors of AGD in dogs are breed, overeating, aerophagia, stress and gastric dysrhythmias (Lippencott \& Schulman 1989, Todoroff 1992, Eggertsdóttir 1995, Burrows \& Ignaszewski 1990). Not many of these are readily applicable to cats. Although the underlying causes of primary AGD remain unknown, mechanically or functionally impaired gastric outflow at either the gastroesophageal sphincter or the pylorus occurs, and causes may be the same in both dogs and cats. In cats experiencing trauma including diaphragmatic hernia secondary AGD can be caused by displacement of abdominal organs into the thoracic cavity and obstruction of the gastric outlet. Considering that $30 \%$ of the cats with AGD also had diaphragmatic hernia, 
might indicate that AGD is an underestimated sequel to diaphragmatic hernia.

Since AGD in cats is rare, the fact that only one recurrence has been reported (Table 1) does not necessarily mean that recurrences are rare. In dogs, several studies have shown that the recurrence rate is high if treatment does not include gastropexy (Woolfson \& Kostolich 1986, Whitney et al. 1989, Frendin \& Funkquist 1990).

The prognosis for dogs with AGD depends on their present clinical condition and how quickly appropriate therapy is initiated. Still many dogs die prior to commencement of treatment or post-operatively and mortalies of $30 \%$ to $40 \%$ have been recorded (Willard 1995). Judging from the information gained from 10 cases of AGD in cats (Table 1) these statements seem also to apply to cats.

Cats behave differently than dogs and many tend to isolate themselves or disappear when they become ill. Traditionally significantly fewer autopsies are performed on cats than dogs. These factors may contribute substantially to the fact that so few cases of AGD in cats have been reported, and that recurrences are correspondingly seldom as compared to their canine counterpart.

\section{Conclusion}

Clinical signs and treatment of AGD in cats are comparable to the similar condition in dogs. Differences in age and etiology of AGD between cats and dogs seem apparent by reviewing the literature. More information is needed to fully assess the prognosis and low recurrence rate of AGD in cats. These conclusions are based on 10 existing reports of AGD in cats and cautiousness in overinterpretation is therefore warranted.

\section{References}

Austefjord $\emptyset$, Bredal $W$ Hva er diagnosen? (What is your diagnosis?) Nor. Vet.-T. 1994, 106, 649-650.

Betts $C W$, Wingfield WE, Greene RW: A retrospective study of gastric dilatation-torsion in the dog. J. Small Anım. Pract. 1974, 15, 727-733.

Burrows CF, Ignaszewski LA: Canine gastric dilatation-volvulus. J. Small Anım. Pract. 1990, 31, 495-501.

de Grestı A, Leonardi L. Torsione acuta dello stomaco nel gatto. Prima segnalazione di un caso. (Acute gastric torsion in a cat). La Clinica Veterinaria 1968, 91, 205-210.

Eggertsdóttr $A V^{\cdot}$ Magedreıning hos hund. En litteraturoversikt. (Gastric dilatation volvolus in dogs. A literature review). Nor. Vet.-T. 1995, 107, 11-20.

Frendin J, Funkquist B: Fundic gastropexy for prevention of recurrence of gastric volvulus. J. Small Anım. Pract. 1990, 31, 78-82.

Herr DM, Thompson PL, Cunningham JH: What is your diagnosis? J. Amer. vet. med. Ass. 1973, 162, 491-492.

Key DM: Dilation and torsion of the stomach in a cat. Felıne Pract. 1977, 7, 38-39.

Kieval RS, Dykes NL: What is your diagnosis? J. Amer. vet. med. Ass. 1977, 194, 819-820.

Lippencott CL, Schulman AJ· Gastric dilatation-volvulus-torsion syndrome. In: S.J. Ettinger (ed): Textbook of internal medicine. 3rd ed. WB Saunders Co, Philadelphia 1989, p. 1278-1288.

Nathans I- Twee gevallen van acute maagdilatatie bij de kat. Tijdschrift voor Diergeneeskunde 1984, 109, 1036-1037.

Scholl H: Magenüberladung bei einer Katze (Gastric dilatation in a cat). Kleintier Praxis 1979, 24, 41-42.

Todoroff $R J \cdot$ Gastric dilatation-volvulus. In: The compendium collection: Emergency medicine and critıcal care in practice. Veterinary Learning Systems Co, Trenton 1992, p. 155-162.

Turner T: Clinical Communication: A Case of Torsion of the Stomach in a Five-Year-Old Cat. J. Small Anim. Pract. 1968, 9, 231-233.

Turner T: A case of torsion of the stomach in an 11year-old Dachshund bitch. Vet. Rec. 1964, 76, 243.

Van Kruiningen HJ, Gregoire K, Meuten DJ: Acute gastric dilatation: A review of comparative aspects, and a study in dogs and monkeys. J. Amer. Anım. Hosp. Ass. 1974, 10, 294-324.

Whitney WO, Scavelli TD, Matthiesen DT, Burk RL Belt-loop gastropexy: Technique and surgical results in 20 dogs. J. Amer. Anim. Hosp. Ass. 1989, $25,75-83$. 
Willard MD: Diseases of the stomach. In: Ettınger and E.C. Feldman (eds.): Textbook of internal medicine. 4th ed. WB Saunders Co, Philadelphia 1995, p. 1161-1163.

Wingfield WE, Betts CW, Rawlings CA: Pathophysiology associated with gastric dilatation-volvulus in the dog. J. Amer. Anim. Hosp. Ass. 1976, 12, 136-142.

Woolfson J, Kostolich M. Circumcostal gastropexy: Clinical use of the technique in 34 dogs with gastric dilatatıon-volvulus. J. Amer. Anım. Hosp. Ass. 1986, 22, 825-830.

\section{Sammendrag \\ Akutt magedilatasjon hos katt.}

Magedılatasjon er en velkjent, akutt, livstruende tılstand hos hund. Tilsvarende tilstand hos katt er langt mindre kjent. Artıkkelen beskriver 2 tilfeller av akutt magedılatasjon hos katt som er sett av forfatterne. Foruten disse 2 tilfellene er 8 andre tilfeller av magedilatasjon hos katt beskrevet i litteraturen. Ingen rase- eller kjønnsdisposisjon ble funnet. Aldersfordelingen blant katter med magedilatasjon varierte fra 11 uker til 13 år. Alle de 10 kattene med magedilatasjon hadde forstørret bukomfang ved presentasjon. I de 3 tilfellene hvor dette var det eneste kliniske funnet viste det seg å være ukompliserte magedilatasjoner som lett ble korrigert med ventrikkeldekomprimering. Fire av 10 katter hadde foruten forstørret bukomfang også dyspaé. Siden bare en av disse overlevde medfører denne kombinasjonen en reservert prognose. Fem av kattene hadde magedreining og av disse hadde to diafragmabrokk. Fire av disse overlevde den kırurgiske behandlıngen. Diafragmabrokk ble diagnostisert hos 3 katter og innebærer at større plass for ventrikkelen som et brokk gir kan bidra til dannelsen av magedilatasjon/dreıning.

Tre av 10 katter med diagnosen akutt magedilatasjon døde. Behandling bestående av sjokkterapi, ventrikkeldekomprimering eller kirurgi var vellykket 17 tilfeller. Prognosen er gunstig dersom katten overlever den akutte behandlingen. Residiv er bare registrert hos en katt.

Kliniske symptomer og behandling av akutt magedilatasjon/dreining er like hos hund og katt, mens aldersfordelıngen og etıologien synes å være ulıke. Ytterligere kasus er nødvendig for å kartlegge prognose og residivfrekvens.

(Received Aprll 11, 1996; accepted July 25, 1996).

Reprints may be obtained from: W.P. Bredal, Department of Pharmarology, Microbiology and Food Hygiene, Norwegian College of Veterınary Medicine, P.O. Box 8146 Dep, N-0033 Oslo, Norway. e-mail: w1lliam.bredal@veths.no, fax: +47 22964965 , tel: +47 22964969. 
